\title{
8 Replanting reduces frog diversity in oil palm
}

9 David J. Kurz ${ }^{1,5,6}$, Edgar C. Turner ${ }^{1}$, Agung A.K. Aryawan ${ }^{2}$, Hannah C. Barkley ${ }^{3}$, Jean-Pierre

10 Caliman $^{2}$, Oliver Konopik ${ }^{4}$, Sudharto Ps. ${ }^{2}$, and William A. Foster ${ }^{1}$

11

$12{ }^{1}$ Department of Zoology, University of Cambridge, Downing Street, Cambridge, CB2 3EJ, UK

$13{ }^{2}$ SMART Research Institute, PT SMART Tbk, Jalan Tenku Umar 19, 28112 Pekan Baru,

14 Indonesia

$15{ }^{3}$ Massachusetts Institute of Technology-Woods Hole Oceanographic Institution Joint Program in

16 Oceanography, Woods Hole, MA 02543, U.S.A.

$17{ }^{4}$ Department of Animal Ecology and Tropical Biology, University of Würzburg, Theodor-

18 Boveri-Institut, Biozentrum, Am Hubland, D-97074 Würzburg, Germany

$19{ }^{5}$ Current: Department of Environmental Science, Policy \& Management, University of California

20 - Berkeley, Berkeley, CA, U.S.A. 94720

$21 \quad{ }^{6}$ Corresponding author: dave.kurz@gmail.com

22 Word count: 4029 (excluding title page, abstract, literature cited, tables, and figures)

23 Received ; Revision accepted 


\section{Abstract}

25 A growing body of literature has demonstrated significant biodiversity losses for many taxa

26 when forest is converted to oil palm. However, no studies have directly investigated changes to

27 biodiversity throughout the oil palm life cycle, in which oil palm matures for 25-30 yr before

28 replanting. This process leads to major changes in the oil palm landscape that likely influence

29 species assemblages and ecosystem function. We compare frog assemblages between mature

30 (21-27 yr old) and recently replanted (1-2 yr old) oil palm in Sumatra, Indonesia. Across

31 eighteen 2.25-ha oil palm plots, we found 719 frogs from 14 species. Frog richness was 31

32 percent lower in replanted oil palm (9 species) than mature oil palm (13 species). Total frog

33 abundance was 47 percent lower in replanted oil palm, and frog assemblage composition differed

34 significantly between the two ages of oil palm. The majority of frog species were disturbance-

35 tolerant, although we encountered four forest-associated frog species within mature oil palm

36 despite a distance of $28 \mathrm{~km}$ between our study sites and the nearest extensive tract of forest.

37 Although it is clear that protection of forest is of paramount importance for the conservation of

38 tropical fauna, our results indicate that management decisions within tropical agricultural

39 landscapes also have a profound impact on biodiversity. Practices such as staggered replanting or

40 variable retention of mature oil palm patches could help maintain frog diversity in the oil palm

41 landscape.

42 Key words: alpha diversity; amphibian; biodiversity loss; plantation management; SE Asia;

43 Sumatra; tropical agriculture; working landscapes 


\section{Indonesian Abstract}

48 Semakin banyak publikasi (tulisan ilmiah) yang menyebutkan bahwa terjadi kehilangan

49 biodiversitas yang nyata, ketika hutan dikonversi menjadi perkebunan kelapa sawit. Namun

50 belum ada studi yang langsung ditujukan untuk meneliti perubahan biodiversitas sepanjang

51 siklus hidup kelapa sawit, yakni selama periode 25-30 tahun sebelum akhirnya kelapa sawit

52 tersebut dilakukan penanaman ulang (replanting). Proses tersebut akan mengakibatkan

53 perubahan besar tata ruang di dalam perkebunan kelapa sawit yang mungkin akan mempengaruhi

54 keragaman jenis organisme dan fungsi dari ekosistem. Kami membandingkan keragaman katak

55 pada areal kelapa sawit menghasilkan (TM) (umur 21-27 tahun) dengan areal kelapa sawit yang

56 belum menghasilkan (TBM) bekas tanam ulang (ex replanting) (umur 1-2 tahun) di Sumatra,

57 Indonesia. Dari pengamatan yang dilakukan pada 18 petak pengamatan, masing-masing seluas

582,25 ha kelapa sawit, kami menemukan 719 ekor katak dari 14 jenis katak. Kekayaan jenis katak

5931 persen lebih rendah pada areal kelapa sawit TBM bekas tanam ulang (9 jenis) dibandingkan

60 dengan pada areal kelapa sawit TM (13 jenis). Total kelimpahan jenis katak 47 persen lebih

61 rendah pada areal tanaman kelapa sawit TBM bekas tanam ulang, dan komposisi kumpulan katak

62 berbeda nyata antara kedua lokasi pengamatan tersebut. Sebagian besar jenis katak tersebut

63 adalah jenis yang toleran terhadap gangguan lingkungan. Walaupun demikian, kami juga

64 menjumpai 4 jenis katak yang berasosiasi dengan habitat hutan, di dalam areal kelapa sawit TM,

65 meskipun jarak antara tempat studi kami dengan hamparan hutan terdekat minimum $28 \mathrm{~km}$.

66 Walaupun jelas bahwa perlindungan hutan adalah hal yang paling penting untuk melindungi

67 keberadaan binatang (fauna) di daerah tropis, namun hasil penelitian kami menunjukkan bahwa

68 keputusan pengelolaan tata ruang pertanian juga dapat memberikan dampak yang besar di dalam

69 biodiversitas fauna tersebut. 
70 Praktek pengelolaan perkebunan seperti pengaturan giliran tanam ulang atau perbedaan panjang

71 masa produksi kelapa sawit dapat membantu pengelolaan diversitas katak di dalam perkebunan

72 kelapa sawit.

DEFORESTATION TO MAKE ROOM FOR EXPANDING AGRICULTURE IS WIDELY RECOGNIZED AS A

75 leading threat to terrestrial biodiversity (Koh \& Wilcove 2008, Rudel et al. 2009, Vié et al. 2009,

76 Wilcove \& Koh 2010, Laurance et al. 2014). Nonetheless, agricultural areas can support

77 substantial biodiversity, which is valuable inherently as well as for the sustainable function of

78 agricultural landscapes (Balvanera et al. 2006), increased ecosystem resilience (Elmqvist et al.

79 2003), and better human health (Chivian 2002). Plantations are particularly important, as they:

80 (1) have been shown to play a role in conserving biodiversity (Brockerhoff et al. 2008, Pawson

81 et al. 2013); (2) can be readily modified to better accommodate biodiversity (Mang \& Brodie

82 2015); and (3) will occupy an increasingly large proportion of human-modified landscapes

83 (Hartley 2002). A major characteristic of plantation crops such as coffee, mahogany, rubber, and

84 oil palm is that they are routinely clear-cut and replanted (Sim \& Nykvist 1991, Mayhew et al.

85 2003, Ruf \& Lançon 2004, Ooi \& Heriansyah 2005). Thus, it is critical that more research be

86 done to develop intelligent replanting schemes that are as biodiversity-friendly as possible while

87 also balancing factors such as yield effects, cost, and disease (Luskin \& Potts 2011). This is

88 particularly true for oil palm (Elaeis guineensis), which, owing to its high structural complexity

89 and long life span in comparison to other forms of agriculture, has the potential to support

90 relatively high levels of biodiversity (Foster et al. 2011).

91 Understanding the best ways to replant oil palm is also urgent, as a disproportionate area

92 of senescent oil palm is currently due for replanting, given the boom in oil palm cultivation in the 
93 mid-1980s and the 25-30 yr life cycle of the crop (Snaddon et al. 2013). Replanting allows

94 growers to more easily assess fruit ripeness and also typically increases crop production, as a

95 block of aging oil palm is replaced with a newer, hardier, and higher-yielding strain (Corley \&

96 Tinker 2003). Replanting usually occurs through felling of oil palm trees followed by either

97 stacking or chipping the trunks and then planting oil palm seedlings. Prevailing wisdom within

98 the oil palm industry also recommends the planting of leguminous vegetation, which increases

99 biological nitrogen fixation, stores nutrients, and then slow-releases organic matter back into the

100 oil palm as the legumes die following closure of the oil palm canopy (Agamuthu \& Broughton

101 1985). Legumes are also thought to help prevent beetle invasions, stem soil runoff, and reduce

102 disease spread (Chee 2007, Goh et al. 2007, Noor et al. 2013).

103 While there has been significant attention paid to best practices for replanting in terms of

104 oil palm health, there has been very little research focused on the relationship between replanting

105 methods and biodiversity. As is the case with much decision-making in the conservation world at

106 large (Sutherland et al. 2004), there is a great need for more scientific evidence behind oil palm-

107 related conservation decisions (Turner et al. 2008, Foster et al. 2011). As it currently stands, the

108 oil palm industry typically makes management decisions based primarily on economic factors

109 (e.g. Noor 2003, Ruf \& Lançon 2004), although sustainability efforts are increasing (e.g. RSPO

110 2007).

111 The current modus operandi of replanting involves clearing large (1-5 km) swaths of

112 mature oil palm all at once, leading to extensive areas of homogeneous vegetation (Luskin \&

113 Potts 2011). Luskin \& Potts therefore advocate novel, staggered replanting schemes designed to

114 increase vegetative heterogeneity at the landscape scale. They argue that greater vegetative

115 diversity in the oil palm landscape will increase habitat heterogeneity, thereby supporting a 
116 greater diversity of species. While their conceptual models have yet to be tested, they accord

117 with empirical studies that link increased vegetative complexity in the matrix to increased

118 biodiversity (Kanowski et al. 2006, Kurz et al. 2014).

119 While it is clear that preserving large tracts of forest is the top priority for conserving

120 tropical biodiversity (Barlow et al. 2007, Gibson et al. 2011), management in plantations and

121 other agricultural areas is also important as part of a comprehensive conservation strategy to

122 support biodiversity and ecosystem function within and across landscapes (Daily et al. 2001,

123 Hartley 2002, Foster et al. 2011). Although several studies have found differences in frog

124 assemblages in forest and oil palm (Gillespie et al. 2012, Faruk et al. 2013, Gallmetzer \&

125 Schulze 2015, Konopik et al. 2015), ours is the first to examine changes in frog assemblages

126 between mature and recently replanted oil palm. We also suggest ways that conservation

127 practitioners and oil palm estate managers can identify which species are being harmed by

128 current management methods and better conserve frog assemblages in tropical working

129 landscapes through more biodiversity-friendly replanting practices.

\section{METHODS}

133 StUdy AREA AND SAMPLING DESIGN. - Fieldwork took place in Sumatra, Indonesia, in

134 partnership with the Biodiversity and Ecosystem Function in Tropical Agriculture (BEFTA)

135 Project collaboration between the University of Cambridge and the Sinar Mas Agro Resources

136 and Technology Research Institute, SMARTRI (Foster et al. 2014;

137 www.oilpalmbiodiversity.com). The BEFTA Project is located in actively managed oil palm

138 estates owned and managed by Pt Ivo Mas Tunggal, a company owned by Golden Agri 
139 Resources and with technical advice from Pt Smart. The estates are located in the Siak regency

140 of Riau province, Sumatra $\left(0^{\circ} 55^{\prime} 56^{\prime \prime} \mathrm{N}, 101^{\circ} 11^{\prime} 62^{\prime \prime} \mathrm{E}\right)$. This area receives an average rainfall of

$1412.4 \mathrm{~m} / \mathrm{yr}$, with the natural landscape characterized by wet lowland forest on sedimentary soils.

142 Our study area was logged in the 1970s and the resulting degraded logged forest was converted

143 to oil palm from 1985-1995. At the regional scale, between 1990 and 2012 tropical forest cover

144 in Riau declined from 63 percent to 22 percent mainly due to oil palm expansion (Ramdani \&

145 Hino 2013).

146 The estates are a mixture of mature and recently replanted oil palm. The area surrounding

147 the estates is mainly mature oil palm, with varying amounts of other crops. Our study included

148 twelve 2.25-ha plots of mature oil palm (21-27 yr old) and six plots of recently replanted oil

149 palm (1-2 yr old). We obtained different sample sizes for the two ages of oil palm because data

150 for the mature plots was collected as part of a larger manipulative study (Foster et al. 2014). To

151 minimise variation among plots, all plots were established in flat areas 40-60 m asl. Understory

152 vegetation is generally abundant in between the oil palm trees, except along harvesting paths,

153 which are located along every other oil palm row and are kept open to facilitate access to the

154 palms. In the replanted plots, this vegetation is dominated by Mucuna bracteata that is planted

155 between the oil palm rows. Replanted plots also contain logs and litter from the previous mature

156 oil palm trees, which are cut and stacked between the new replanted rows. Mature plots

157 contained palm trees $12-15 \mathrm{~m}$ in height with a closed canopy and replanted areas contained trees

$158 \quad 2.5-4 \mathrm{~m}$ in height with an open canopy. Due to the replanting schedule, recently replanted plots

159 could not be paired with mature plots, but were selected to be no more than $15 \mathrm{~km}$ from the

160 mature plots (Fig. S1). The sole remnant forest patch within the oil palm estates is a 112-ha

161 fragment of low-quality secondary swamp forest located $1 \mathrm{~km}$ from our nearest sampling site. 
162 The closest extensive forest area ( $>5000 \mathrm{ha})$ is $>28 \mathrm{~km}$ from all our sites. One-third of replanted

163 plots and one-fourth of mature plots contained some form of standing or slow-moving water (i.e.

164 stream, spring, or pond) at the time of the study.

165

166 AMPHIBIAN SAMPLING.- - In both replanted and mature plots we conducted frog surveys around

167 the perimeter of a $50 \times 50 \mathrm{~m}$ square area. Each square transect was sampled three times over the

168 course of six wk and all sampling occurred at night between 1900-0200 h. Sampling took place

169 during the dry season in February and March 2014; weather during the sampling period averaged

170 only $0.007 \mathrm{~mm} / \mathrm{d}$ rain in Libo Estate in February 2014 and $1.81 \mathrm{~mm} / \mathrm{d}$ in March, compared to a

171 monthly average of $5.51 \mathrm{~mm} / \mathrm{d}$ (calculated over the period 1 January 2012 - 31 August 2014).

172 These consistently dry conditions meant that weather was comparable for all sampling of plots

173 throughout the study period. In addition, we rotated sampling between mature and replanted

174 plots to help control for any minor weather-related variability. We used distance- and time-

175 constrained visual encounter surveys to sample frogs (Kurz et al. 2014). For each transect, one

176 observer (DJK) walked slowly for one $\mathrm{h}$ along the perimeter of the $50 \times 50 \mathrm{~m}$ square, lightly

177 disturbing vegetation and searching for frogs within 2-m of either side of the perimeter and from

178 0-2.5 $\mathrm{m}$ above the ground (von May et al. 2010). Each frog observed was captured and

179 identified with the help of a field guide for Borneo (Inger \& Stuebing 2005, the best available

180 resource for the identification of the frogs of Sumatra) and then released. Photographs were

181 taken as necessary for further identification. Time needed for capture and identification was

182 excluded from the one $\mathrm{h}$ limit. The observer noted the microhabitat in which each frog was found

183 (categories included: fern, ground, forb, palm litter, empty fruit bunch, or other), the height of 
184 the frog off the ground $(0,0-0.5 \mathrm{~m}, 0.5-1 \mathrm{~m}$, etc), and whether the frog was within $5 \mathrm{~m}$ of a water

185 source.

187 ENVIRONMENTAL VARIABLES.-Environmental variables were also recorded along the perimeter

188 of the $50 \times 50 \mathrm{~m}$ square area. We collected data on vegetation cover, canopy cover, and

189 temperature. Vegetation cover was recorded at 20 points along the $200 \mathrm{~m}$ transect perimeter. At

190 each point, a single observer (AAKA) estimated vegetation cover in a $16 \mathrm{~m}^{2}$ plot to the nearest 5

191 percent according to seven categories: bare ground, fern, forb, fallen palm frond, empty fruit

192 bunch, dead vegetation, and other. Vegetation estimates were then averaged across the 20 points

193 to give a score for each plot.

$194 \quad$ Percent canopy cover was collected using a convex spherical densiometer (Lemmon

195 1956). Night and daytime temperature data were collected using high-capacity Thermochron ${ }^{\circledR}$

196 iButtons (Maxim Integrated, San Jose, California) placed $1 \mathrm{~m}$ above the ground and set for an

197 average of seven $d$ at each plot, collecting readings every three h.

199 DATA ANALYSIS.- Statistical analyses were conducted in the 'vegan' and 'BiodiversityR' (Kindt

200 \& Coe 2005) packages in R (Team R 2013), and EstimateS Version 9.1.0 (Colwell 2013) was

201 used to construct rarefaction curves. Survey data from all three transect visits at each plot were

202 pooled before analysis. We tested for spatial autocorrelation of species richness results within the

203 datasets for each plot type and found no spatial autocorrelation for either mature plots (Moran's $I$

$204=0.08, P=0.35$ ) or replanted plots (Moran's $I=-0.39, P=0.51$ ). Because richness data did not

205 meet assumptions for normality and homoscedasticity, we used Mann-Whitney U tests to

206 compare species richness and a Welch's $t$-test to compare abundance between mature and 
207 replanted plots. To estimate species richness in each oil palm type, we used Chao 1, a simple

208 species richness estimator based on the number of rare species in the sample (Chao 1984).

209 To test for differences in community composition between mature and replanted plots,

210 we ran a permutational multivariate analysis of variance (PERMANOVA, Anderson 2001) with

21110,000 permutations on fourth-root standardized Bray-Curtis dissimilarities. We then calculated

212 the contributions of each species to overall dissimilarity using the 'simper' function in the $\mathrm{R}$

213 package 'vegan' (Oksanen et al. 2013). We used redundancy analysis (RDA) to visualise

214 relationships among frog species, mature and replanted oil palm plots, and water availability in

215 the plots (Kindt \& Coe 2005). Because water sources were variable and difficult to quantify

216 precisely across oil palm plots, we used the average number of frogs per transect observed within

$2175 \mathrm{~m}$ of water as a proxy for water availability.

218 To compare the environmental variables across habitat types, we first tested the data for

219 each environmental variable for normality and homoscedasticity. We then ran Welch's $t$-tests on

220 variables with normal and homoscedastic data and Mann-Whitney U tests on variables with non-

221 normal and non-homoscedastic data, and applied a Bonferonni correction to account for multiple

222 comparisons (Whitlock \& Schluter 2009).

\section{RESULTS}

226 Frog assemblages.-Across 18 oil palm plots, we sampled 719 individual frogs representing

22714 species from 6 families. We found a total of 13 species in mature plots and 9 species in

228 replanted plots (Table 1). Of the nine species found in replanted palm, only one (Hylarana

229 nicobariensis) was not found in mature palm as well. However, five species occurred in mature 
230 plots that were not encountered in replanted oil palm: Duttaphrynus melanostictus, Humerana

231 miopus, Leptobrachium nigrops, Limnonectes paramacrodon, and Polypedates colletti. Most

232 species recorded were generalists that are known to thrive in various types of forest and

233 agricultural habitats, although three of the species found only in mature oil palm - L. nigrops, $L$.

234 paramacrodon, and $P$. colletti - are thought to dwell almost exclusively in forest (Inger \&

235 Stuebing 2005, IUCN 2015). We could not assign a species to frogs of the genus Microhyla

236 given the lack of clear frog identification resources for Sumatra. Because of this significant lack

237 of regional information as well as the varying habitat preferences of frogs in the genus

238 Microhyla, we did not consider the Microhyla sp. in our study as either generalist or

239 predominantly forest-associated. Additionally, we opportunistically encountered Kalophrynus

240 punctatus (a forest-associated, IUCN-listed 'Vulnerable' species) outside of our transect area in

241 mature oil palm. One half of the species we encountered on our transects $-H$. chalconota,

242 H. glandulosa, H. miopus, H. nicobariensis, L. nigrops, L. paramacrodon, and P. colletti - are

243 endemic to Sundaland, as is K. punctatus.

244 Per-plot frog species richness was higher in mature oil palm than in replanted palm

245 (Mann-Whitney $\mathrm{U}$ test, $U=63, P=0.01$; Fig. 1A), as was per-plot frog abundance (Welch's $t$ -

246 test, $P=0.02$, Fig. 1B). Rarefaction curves for all samples combined across sites also showed

247 higher species accumulation in mature oil palm (Fig. 2), with an estimated richness (given by

248 Chao 1) of 13.5 species for mature plots and 10 species for replanted plots. There was also a

249 significant difference in frog assemblage composition between plot types (PERMANOVA, $F_{1,16}$

$250=5.34, P=0.001)$.

251 The first two axes in the redundancy analysis explained 43.6 percent of the variation in

252 frog assemblages among sites (Fig. 3). More species were positively associated with mature plots 
253 compared to replanted plots. P. leucomystax and H. chalconota clustered towards water.

254 Similarity percentages (SIMPER) showed that P. leucomystax, H. chalconota, H. miopus, and

255 Microhyla sp. contributed most to the average overall Bray-Curtis dissimilarity between mature

256 and replanted plots (Table S1).

258 ENVIRONMENTAL VARIABLES. - All environmental variables differed significantly $(P<0.001)$

259 between mature and replanted oil palm. Replanted plots contained less fern cover (-94\%),

260 canopy cover (-96\%), bare ground (-63\%), palm fronds (-100\%), and empty fruit bunches

261 (-92\%). Replanted plots were also characterized by more herbaceous plant cover $(+341 \%)$,

262 higher day-time temperatures $\left(+3.3^{\circ} \mathrm{C}\right)$, and lower night-time temperatures $\left(-1.6^{\circ} \mathrm{C}\right)$.

264 Microhabitat PREFERENCES.- - In mature plots, we found more frogs on bare ground than in

265 any other microhabitat, whereas in replanted oil palm we found frogs most commonly on the

266 ground-cover legume M. bracteata. Frogs in mature plots were also commonly found in fern,

267 forb, and fallen palm frond microhabitats. The average height at which frogs were encountered

268 was significantly higher in replanted oil palm $(0.60 \mathrm{~m})$ than mature oil palm $(0.38 \mathrm{~m})$ (Mann-

269 Whitney $\mathrm{U}$ Test, $\mathrm{W}=37070, P<0.001)$. For the four species of frogs found four or more times

270 in both mature and replanted oil palm, three showed a change in most commonly occupied

271 microhabitat: Microhyla sp. (ground in mature, forb in replanted); H. chalconota (fern in mature,

272 forb in replanted); and P. leucomystax (fern in mature, forb in replanted).

\section{DISCUSSION}


276 Our study is the first to examine and demonstrate the loss of frog diversity and a change in frog 277 assemblage composition between mature and recently replanted oil palm. These findings add an

278 additional layer of understanding to several others that show lower frog richness (Gallmetzer \&

279 Schulze 2015, Konopik et al. 2015) and a difference in frog assemblages (Gillespie et al. 2012,

280 Faruk et al. 2013, Gallmetzer \& Schulze 2015, Konopik et al. 2015) in oil palm as compared to

281 forest. Our results point to new ways that conservation of tropical frogs can move forward via a

282 more nuanced understanding of tropical plantation systems and their potential value for

283 preserving frog diversity and function in agricultural landscapes.

THE INFLUENCE OF ENVIRONMENTAL VARIABLES ON FROG ASSEMBLAGES.- Environmental

286 variables seemed to be a major driver behind the significantly more abundant and species-rich

287 frog assemblages in mature oil palm. Critically, mature plots contained closed canopies with

$28873.8-89.1$ percent canopy cover, compared to replanted palm plots, which essentially lacked any

289 canopy cover. The open canopy and resulting lack of temperature stability that we saw in our

290 replanted oil palm plots could make it difficult for frogs to colonize, survive, and reproduce in

291 replanted oil palm patches, particularly during warm or dry spells. Other studies show that

292 replanted oil palm is hotter and drier than mature oil palm (Luskin \& Potts 2011, Hardwick et al.

293 2015), and frogs are susceptible to desiccation as temperature increases and humidity decreases

294 (Rittenhouse et al. 2008, Nowakowski et al. 2015).

295 Vegetation cover was another major environmental factor that likely contributed to

296 observed differences in frog assemblage structure. Across a broad range of ecosystems,

297 vegetation structure is known to play a role in shaping frog ensembles (e.g., Parris \& McCarthy

298 1999, Jansen \& Healey 2003, Urbina-Cardona et al. 2006). The M. bracteata legume that is 
299 widely planted in Sumatra between rows of replanted palm was by far the most common type of

300 vegetation in replanted oil palm ( $>80 \%$ cover across all replanted plots). By comparison, mature

301 plots had a greater mixture of bare ground, fern, fallen palm fronds, forbs, and empty fruit

302 bunches. It is possible that the homogeneity of the forbaceous cover in replanted palm plots is

303 not as conducive to attracting as diverse a suite of frog species as the more heterogeneous

304 vegetative structure of mature plots.

306 THE IMPORTANCE OF MICROHABITAT OPTIONS.-For the four frog species found commonly in

307 both types of oil palm, three showed a change in their most frequently occupied microhabitat

308 between mature and replanted palm. This pattern was likely due to decreased microhabitat

309 diversity in replanted palm. Replanted oil palm contained an overwhelming majority of $M$.

310 bracteata forbaceous cover and therefore contained far less fern cover, far fewer patches of bare

311 ground, and no palm trunks (as old palm trunks were chipped at replanting) as compared to the

312 older oil palm. Also, frogs were found significantly higher off the ground in replanted palm

313 plots, further indication of shifting niches. Environmental heterogeneity has been shown to

314 influence species diversity and assemblage structure in other tropical amphibian assemblages

315 (Keller et al. 2009).

317 Oil PALM AND FROG ASSEMBLAGE COMPOSITION.- Replanted palm plots were 20-25 yr younger

318 than mature plots, and thus did not have time to recover from the severe disturbance event of

319 replanting and develop the greater microclimate buffering, increased canopy cover, and greater

320 leaf litter cover of older oil palm plots (Luskin \& Potts 2011). Perhaps because of the more

321 favorable microclimate conditions in mature oil palm, older plots may be more accessible to not 
322 only a broader assemblage of disturbance-tolerant species, but also species that typically thrive in

323 forested areas. On our transects we encountered L. paramacrodon, L. nigrops, and P. colletti,

324 three forest-associated species (Inger \& Stuebing 2005), as well as an opportunistic sighting of

325 the forest species Kalophrynus punctatus. The presence of these species indicates that species

326 traditionally considered forest-associated can inhabit oil palm. Furthermore, the lack of any

327 extensive (> $5000 \mathrm{ha}$ ) forest tracts within $28 \mathrm{~km}$ of our oil palm plots, and the fact that the plots

328 were originally established 20-30 yr ago, suggests that some forest-associated frogs are able to

329 sustain populations in oil palm independent of a forest source population.

330 In several ways, our results align with the findings of other studies on frog assemblages

331 in oil palm. As in our study, Gillespie et al. (2012), Faruk et al. (2013), Gallmetzer and Schulze

332 (2015), and Konopik et al. (2015) encountered frog assemblages in oil palm dominated by

333 disturbance-tolerant species. Thus, across all studies on frogs in oil palm including ours, frog

334 ensembles were impoverished in their reflection of known endemic and forest-associated species.

335 Several of the same SE Asian generalist frog species, including Hylarana erythraea, Hylarana

336 nicobariensis, Fejervarya limnocharis (recorded as Fejervarya sp. in our study given the

337 similarity between $F$. limnocharis and F. cancrivora and the lack of frog ID guides for Sumatra),

338 and Polypedates leucomystax, were common in oil palm plantations in our study as well as other

339 studies on frogs in oil palm in SE Asia (Gillespie et al. 2012, Faruk et al. 2013, Konopik et al.

340 2015). Like Faruk et al. (2013) but unlike Gillespie et al. (2012) and Konopik et al. (2015), we

341 found multiple microhylid species in oil palm. We found four forest-associated species within

342 mature oil palm located $>28 \mathrm{~km}$ from any large tracts of forest, which lends additional support to

343 the possibility that untapped potential exists for frog conservation in oil palm landscapes

344 (Konopik et al. 2015). 
346 CONSERVATION RECOMMENDATIONS.-Based on our findings, it seems that the process of clear-

347 cutting and replanting mature oil palm results in the loss of frog species richness and abundance

348 and presumably the loss of ecological functions performed by those frogs. If further studies

349 establish that these results are typical for frogs as well as other taxa, then it will be important to

350 consider replanting strategies that preserve biodiversity in the oil palm landscape, provided that

351 these management practices do not significantly compromise net yield. These strategies might

352 include: reducing the size of areas that are clear-cut and replanted so that habitat heterogeneity is

353 increased at smaller scales (Ramage et al. 2013); maintaining connectivity among swaths of

354 mature oil palm; replanting in continuous bands so that swaths of habitat of the same age are

355 maintained (Luskin \& Potts 2011); and replanting away from waterways in an effort to reduce

356 erosion and thereby maintain “appropriate riparian buffer zones” (RSPO 2007).

357 By increasing both small-scale heterogeneity and connectivity of mature oil palm, it may

358 be possible to avoid the turnover of frog assemblages between mature and replanted plots that,

359 based on our data, included the loss of five species (three of them forest-associated) and greatly

360 decreased abundance of five others (Table 1). While feasible in terms of the machinery required,

361 novel replanting techniques could call for a substantial financial investment on the part of oil

362 palm companies.

363 Amphibians are of central importance in many ecosystems (Wissinger et al. 1999, Whiles

364 et al. 2006), and frogs are among the most abundant vertebrate groups in our study system.

365 Among their many functions, predation in particular may be important; it is generally recognized

366 that maintaining diverse and abundant natural predators in agricultural areas can help reduce pest

367 outbreaks (Wood 2002). Furthermore, the protection of amphibian diversity is urgent given 
368 amphibian declines worldwide (Stuart et al. 2004). Our study shows that mature oil palm can

369 sustain substantial frog diversity and abundance, including three species typically considered

370 forest-associated, and indicates that frog assemblages are likely harmed in the replanting process.

371 We therefore suggest that it is worthwhile to consider how frog populations and their functions

372 might be better conserved during and after replanting in oil palm landscapes.

373

\section{Acknowledgments}

375 We are very grateful to Dr. Mohd Naim and the SMARTRI leadership for their generosity in

376 allowing us to conduct research at SMARTRI alongside their team. We also thank bp Ade

377 Netral, Kurniadi, Darma, Jaka, Bambang, and all the others on the exceptional SMARTRI

378 research assistant team for their assistance in the field. We are indebted to bp Agus and bp

379 Sukardi for kindly driving us to the field sites. We also thank Aude Verwilghen for her advice

380 and details of forest cover in the region, and Evelyne St-Louis for her help with figures. The

381 Isaac Newton Trust and Sinar Mas Agro Resources and Technology funded both the fieldwork

382 and the BEFTA Project. We thank RISTEK for permission for the BEFTA Project and ECT to

383 conduct research in Indonesia (number 426/SIP/FRP/SM/XI/2012,

384 72/EXT/SIP/FRP/SM/IX/2013).

385

386

387

388

389

390 


\section{Literature Cited}

392 Agamuthu, P., And W. J. Broughton. 1985. Nutrient cycling within the developing oil palmlegume ecosystem. Agric. Ecosyst. Environ. 13: 111-123.

394 ANDERSON, M. J. 2001. A new method for non-parametric multivariate analysis of variance. Austral Ecol. 26: 32-46.

Balvanera, P., A. B. Pfisterer, N. Buchmann, J.-S. He, T. Nakashizuka, D. Raffaelli, And functioning and services. Ecology Letters 9: 1146-1156.

Barlow, J., T. A. Gardner, I. S. Araujo, T. C. Ávila-Pires, A. B. Bonaldo, J. E. Costa, M.

406 Brockerhoff, E. G., H. Jactel, J. A. PArrotta, C. P. Quine, And J. SAYer. 2008. Plantation

408 ChaO, A. 1984. Non-parametric estimation of the number of classes in a population. Scand. J. Stat. 11: 265-270.

410 CHeE, K. H. 2007. Mucuna bracteata - a cover crop and living green manure. Agroworld 188: $30-34$.

412 Chivian, E. 2002. Biodiversity: its importance to human health. Boston: Center for Health and 413 the Global Environment, Harvard Medical School. 
Kurz et al.

414 ColwelL, R. K. 2013. EstimateS: Statistical estimation of species richness and shared species 415 from samples. Version 9. Persistent URL < purl.oclc.org/estimates>.

416 Corley, R. H. V., AND P. B. TinKer. 2003. The Oil Palm. Oxford: Blackwell Science Ltd.

417 Daily, G. C, P. R. EhrLich, AND G. A. SÁNCHEZ-AZOFEIFa. 2001. Countryside biogeography: use of human-dominated habitats by the avifauna of Southern Costa Rica. Ecol. Appl. 11:

420 Elmqvist, T., C. Folke, M. Nyström, G. Peterson, J. Bengtsson, B. Walker, And J.

421 Norberg. 2003. Response diversity, ecosystem change, and resilience. Front. Ecol. Environ. 1: 488-494.

423 Faruk, A., D. Belabut, N. Ahmad, R. J. Knell, AND T. W. J. Garner. 2013. Effects of oil424 palm plantations on diversity of tropical anurans. Conserv. Biol. 27: 615-624.

425 Foster, W. A, J. L. Snaddon, E. C. Turner, T. M. Fayle, T. D. Cockerill, M. D. F. Ellwood, 426 G. R. Broad, A. Y. C. Chung, P. Eggleton, C. V. Khen, And K. M. Yusah. 2011. Establishing the evidence base for maintaining biodiversity and ecosystem function in the oil palm landscapes of South East Asia. Philos. Trans. R. Soc. B. 366: 3277-3291.

Foster, W. A, J. L. Snaddon, A. D. Advento, A. A. K. Aryawan, H. Barclay, J-P. Caliman,

434 GallmetZer, N., AND C. H. SChUlze. 2015. Impact of oil palm agriculture on understory C. Kurniawan, D. J. Kurz, D. Mann, M. Naim, P. Dedi, Pujianto, T. S. R. Dzulfikar, E. M. Slade, Soeprapto, Suhardi, P. S. Sudharto, S. T. Ribka, W. Resti, H. W. Rudi, 436 amphibians and reptiles: A Mesoamerican perspective. Global Ecology and Conservation 4: 95-109. 
Gibson, L, T. M. Lee, L. P. Koh, B. W. Brook, T. A. Gardner, J. BArlow, C. A. Peres, C. J. A. Bradshaw, W. F. Laurance, T. E. Lovejoy, and N. S. Sodhi. 2011. Primary forests are irreplaceable for sustaining tropical biodiversity. Nature 478: 378-383.

440 Gillespie, G. R, E. Ahmad, B. Elahan, A. Evans, M. Ancrenaz, B. Goossens, and M. P. SCROGGIE. 2012. Conservation of amphibians in Borneo: relative value of secondary tropical forest and non-forest habitats. Biol. Conserv. 152: 136-144.

443 GoH, K. J., H. H. GAN, AND H. C. PATRICK NG. 2007. Agronomy of Mucuna bracteata under oil 444 palm. In K. J. GoH, AND S. B. CHIU (Eds.). Mucuna bracteata - A cover crop and living 445 green manure, pp. 45-84. Agricultural Crop Trust, Kuala Lumpur, Malaysia.

446 Hardwick, S. R., R. Toumi, M. Pfeifer, E. C. Turner, R. Nilus, and R. Ewers. 2015. The

447 relationship between leaf area index and microclimate in tropical forest and oil palm 448 plantation: forest disturbance drives change in microclimate. Agric. For. Meteorol. $449201: 187-195$.

450 HARTLEy, M. J. 2002. Rationale and methods for conserving biodiversity in plantation forests.

$451 \quad$ For. Ecol. Manage. 155: 81-95.

452 INGeR, R. F, AND R. B. Stuebing. 2005. A field guide to the frogs of Borneo (Second Edition). 453 Natural History Publications, Kota Kinabalu, Malaysia.

454 IUCN 2015. The IUCN Red List of Threatened Species. Version 2015-3.

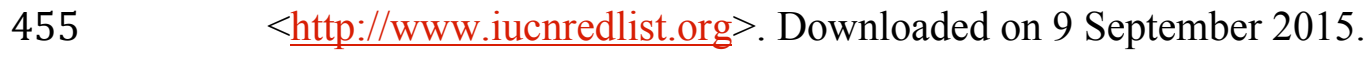

456 JANSEN, A., AND M. HEALEY. 2003. Frog communities and wetland condition: relationships with 457 grazing by domestic livestock along an Australian floodplain river. Biol. Conserv. $458 \quad 109: 207-219$.

459 Kanowski, J. J, T. M. Reis, C. P. CatTerall, AND S. D. PiPer. 2006. Factors affecting the use of 
reforested sites by reptiles in cleared rainforest landscapes in tropical and subtropical Australia. Restor. Ecol. 4: 67-76.

462 Keller, A., M.-O. RöDel, K. E. Linsenmair, And T. U. Grafe. 2009. The importance of 463 environmental heterogeneity for species diversity and assemblage structure in Bornean $464 \quad$ stream frogs. J. Anim. Ecol. 78: 305-314.

465 KINDT, R., AND R. COE. 2005. Tree diversity analysis. A manual and software for common 466 statistical methods for ecological and biodiversity studies. World Agroforestry 467 Centre (ICRAF), Nairobi, Kenya.

468 KOH, L. P, AND D. S. WILCOVE. 2008. Is oil palm agriculture really destroying tropical 469 biodiversity? Conserv. Lett. 1: 60-64.

470 Konopik, O., I. Steffan-Dewenter, AND T. U. Grafe. 2015. Effects of logging and oil palm 471 expansion on stream frog communities on Borneo, Southeast Asia. Biotropica 47: 636472643.

473 Kurz, D. J, A. J. Nowakowski, M. W. Tingley, M. A. Donnelly, And D. S. Wilcove. 2014. $474 \quad$ Forest-land use complementarity modifies community structure of a tropical 475 herpetofauna. Biol. Conserv. 170: 246-255.

476 Laurance, W. F, J. Sayer, and K. G. Cassman. 2014. Agricultural expansion and its impacts 477 on tropical nature. Trends Ecol. Evol. 29: 107-116.

478 Lemmon, P. E. 1956. A spherical densiometer for estimating forest overstory density. For. $479 \quad$ Sci. 2: $314-320$.

480 Luskin, M. S, AND M. D. POTTS. 2011. Microclimate and habitat heterogeneity through the oil 481 palm lifecycle. Basic Appl. Ecol. 12: 540-551. 
Kurz et al.

482 MANG, S. L., AND J. F. BRODIE. 2015. Impacts of non-oil tree plantations on biodiversity in 483 Southeast Asia. Biodivers. Conserv. 24: 3431-3447.

484 Mayhew, J. E, M. Andrew, J. H. Sandom, S. Thayaparan, and A. C. Newton. 2003.

485 Silvicultural systems for big-leaf mahogany plantations. In A. E. Lugo, J. C. Figueroa, and M. Alayón (Eds.). Big-Leaf Mahogany: Genetics, Ecology, and Management, pp. 261-277. Springer, New York, U.S.A.

488 Noor, H. H., Z. A. C. M. RIzUAN, AND H. SuHAidi. 2013. Control measures and integrated approach for major pests of oil palm in FELDA. Malaysia Palm Oil Board Congress

491 NooR, M. 2003. Zero burning techniques in oil palm cultivation: an economic perspective. Oil $492 \quad$ Palm Industry Economic Journal 3: 16-24.

493 Nowakowski, A. J., M. Veiman-Echeverria, D. J. Kurz, And M. A. Donnelly. 2015.

494 Evaluating connectivity for tropical amphibians using empirically derived resistance 495 surfaces. Ecol. Appl. 25: 928-942.

496 Oksanen, J., F. G. Blanchet, R. Kindt, P. Legendre, P. R. Minchin, R. B. O’Hara, G. L.

497 Simpson, P. Solymos, M. Henry, H. Stevens, AND H. WAGner. 2013. vegan:

498 Community Ecology Package. R package version 2.0-10.

499 http://CRAN.R-project.org/package=vegan

500 OOI, L-H, AND S. P. HeRIANSYAH. 2005. Palm pulverisation in sustainable oil palm replanting.

$501 \quad$ Plant Production Science 8: 345-348.

502 PARRIS, K. M, AND M. A. MCCARTHY. 1999. What influences the structure of frog assemblages 503 at forest streams? Aust. J. Ecol. 24: 495-502. 
Kurz et al.

504 Pawson, S. M., A. Brin, E. G. Brockerhoff, D. Lamb, T. W. Payn, A. Paquette, and J. A.

505 PARROTTA. 2013. Plantation forests, climate change and biodiversity. Biodivers.

$506 \quad$ Conserv. 22: 1203-1227.

507 Ramage, B. S., E. C. MarshaleK, J. Kitzes, And M. D. Potts. 2013. Conserving tropical

508 biodiversity via strategic spatiotemporal harvest planning. J. Appl. Ecol. 50: 1301-1310.

509 RAMDANI, F, AND M. HINO. 2013. Land use changes and GHG emissions from tropical forest

$510 \quad$ conversion by oil palm plantations in Riau Province, Indonesia. PLoS ONE 8: e70323.

511 Rittenhouse, T. A. G, E. B. Harper, L. R. Rehard, AND R. D. Semlitsch. 2008. The role of

512 microhabitats in the desiccation and survival of anurans in recently harvested oak-hickory

$513 \quad$ forest. Copeia 4: 807-814.

514 Rountable on Sustainable Palm Oil. 2007. RSPO Principles and Criteria for Sustainable

515 Palm Oil Production. RSPO Criteria Working Group.

516 Rudel, T. K, R. DeFries, G. P. Asner, And W. F. Laurance. 2009. Changing drivers of

517 deforestation and new opportunities for conservation. Conserv. Biol. 23: 1396-1405.

518 RUf, F., AND F. LANÇON. 2004. From Slash and Burn to Replanting: Green Revolutions in the

519 Indonesian Uplands? Washington, D.C.: World Bank.

520 SiM, B. L., AND N. NyKVIST. 1991. Impact of forest harvesting and replanting. J. Trop. For. Sci.

$521 \quad 3: 251-284$.

522 SNADdon, J. L, K. J. WiLlis, AND D. W. MACDONALD. 2013. Biodiversity: oil-palm replanting

$523 \quad$ raises ecology issues. Nature 502: 170-171.

524 Stuart, S. N, J. S. Chanson, N. A. Cox, B. E. Young, A. S. L. Rodrigues, D. L. Fischman,

525 AND R. W. WALLER. 2004. Status and trends of amphibian declines and extinctions

$526 \quad$ worldwide. Science 306: 1783-1786. 
Kurz et al.

527 Sutherland, W. J., A.S. Pullin, P. M. Dolman, And T. M. Knight. 2004. The need for 528 evidence-based conservation. Trends Ecol. Evol. 19: 305-308.

529 TEAm R. 2013. R Development Core Team. R: A Language and Environment for Statistical 530 Computing. Vienna: R Foundation for Statistical Computing. http://www.R-project.org/

531 Turner, E. C., J. L. SnAddon, T. M. FAyle, And W. A. Foster. 2008. Oil palm research in 532 context: identifying the need for biodiversity assessment. PloS One 3: e1572.

533 Urbina-Cardona, J. N., M. Olivares-Perez, AND V. H. Reynoso. 2006. Herpetofauna

534 diversity and microenvironment correlates across a pasture-edge-interior ecotone in 535 tropical rainforest fragments in the Los Tuxtlas Biosphere Reserve of Veracruz, Mexico. $536 \quad$ Biol. Conserv. 132: 61-75.

537 Vié, J. C., C. Hilton-TAYLOR, AND S. N. Stuart. 2009. Wildlife in a changing world - An 538 analysis of the 2008 IUCN Red List of Threatened Species. IUCN, Gland, Switzerland.

539 Von May, R., J. M. Jacobs, R. Santa-Cruz, J. Valdivia, J. M. Huaman, and M. A.

540 DonNelLy. 2010. Amphibian community structure as a function of forest type in

541 Amazonian Peru. J. Trop. Ecol. 26: 509-519.

542 Whiles, M. R, K. R. Lips, C. M. Pringle, S. S. Kilham, R. J. Bixby, R. Brenes, S. Connelly,

543 J. C. Colon-Gaud, M. Hunte-Brown, A. D. Huryn, C. Montgomery, And S.

544 PETERSON. 2006. The effects of amphibian population declines on the structure and

545 function of Neotropical stream ecosystems. Front. Ecol. Environ. 4: 27-34.

546 WhitLock, M., AND D. SCHLUTER. 2009. The analysis of biological data. Roberts and Co.

$547 \quad$ Publishers, Greenwood Village, U.S.A.

548 WiLCOVE, D. S., AND L. P. KOH. 2010. Addressing the threats to biodiversity from oil-palm 549 agriculture. Biodivers. Conserv. 19: 999-1007. 
550 Wissinger, S. A, H. H. Whiteman, G. B. Sparks, G. L. Rouse, and W. S. Brown. 1999.

$551 \quad$ Foraging trade-offs along a predator-permanence gradient in subalpine wetlands.

$552 \quad$ Ecology 80: 2102-2116.

553 Wood, B. J. 2002. Pest control in Malaysia's perennial crops: a half century perspective tracking

554 the pathway to Integrated Pest Management. Integrated Pest Management Reviews

$555 \quad 7: 173-190$.

556

557

558

559

560

561

562

563

564

565

566

567

568

569

570

571

572 
573 TABLE 1. Species list of all frogs encountered on transects in mature and replanted oil palm

574 plots in Riau province, Sumatra, Indonesia. Because of the unequal sample size between mature

$575(n=12)$ and replanted $(n=6)$ plots, and to facilitate direct comparisons between columns, we

576 have divided the numbers in the "Mature" column by two. The "G/F" column indicates whether

577 the species is typically described in the literature as a habitat generalist $(G)$ or forest-associated

578 (F) species (Inger \& Stuebing 2005; IUCN 2015). We use "habitat generalist" to refer to species

579 that can be found in forests and/or various types of disturbed habitats, whereas we use "forest-

580 associated" to refer to species that have been thought to dwell almost exclusively in rain forest.

581 We have not classified Microhyla sp. as either generalist or forest-associated because of the

582 varying habitat preferences of similar species in the genus Microhyla and the lack of detailed

583 frog identification resources for Sumatra. In addition to the species listed here, we

584 opportunistically encountered Kalophrynus punctatus, a forest-associated species listed as

585 "Vulnerable" by the IUCN, outside of our transects, in mature oil palm.

\begin{tabular}{llccc}
\hline Family & \multicolumn{1}{c}{ Species } & G/F & Mature & Replanted \\
\hline Bufonidae & Duttaphrynus melanostictus & G & 3 & 0 \\
Dicroglossidae & Fejervarya sp. & G & 18 & 9 \\
Dicroglossidae & Limnonectes paramacrodon & F & 3 & 0 \\
Megophryidae & Leptobrachium nigrops & F & 1 & 0 \\
Microhylidae & Kaloula baleata & G & 6 & 1 \\
Microhylidae & Kaloula pulchra & G & 3 & 9 \\
Microhylidae & Microhyla sp. & N/A & 28 & 11 \\
Ranidae & Hylarana chalconota & G & 63 & 1 \\
Ranidae & Hylarana erythraea & G & 1 & 7 \\
Ranidae & Hylarana glandulosa & G & 17 & 3 \\
Ranidae & Humerana miopus & G & 40 & 0 \\
Ranidae & Hylarana nicobariensis & G & 0 & 5 \\
Rhacophoridae & Polypedates colletti & F & 1 & 0 \\
Rhacophoridae & Polypedates leucomystax & G & 102 & 106 \\
\hline
\end{tabular}


Kurz et al.

590 FIGURE 1. Average ( \pm SE) frog species richness (A) and abundance (B) per plot in mature (dark

591 gray, $\mathrm{n}=12$ ) and replanted (light gray, $\mathrm{n}=6$ ) oil palm plots, based on data collected in Riau

592 province, Sumatra, Indonesia after three rounds of visual encounter surveys at each plot.

593

594 FIGURE 2. Sample-based rarefaction curves for mature (dark gray) and replanted (light gray)

595 plot types, showing higher species accumulation in mature oil palm. The dashed line shows the

596 extrapolated species richness estimate given more sample sites for replanted oil palm. Data were

597 randomized 100 times. Error bands show standard deviation.

598

599 FIGURE 3. Redundancy analysis ordination plot based on transect data, showing the Euclidean

600 distance between frog species, oil palm plots (circles; dark gray = mature plots, light gray =

601 replanted plots), and water. Plot points closer together contain more similar frog assemblage

602 compositions.

603

604

605

606

607

608

609

610

611

612 
Kurz et al.

613

614

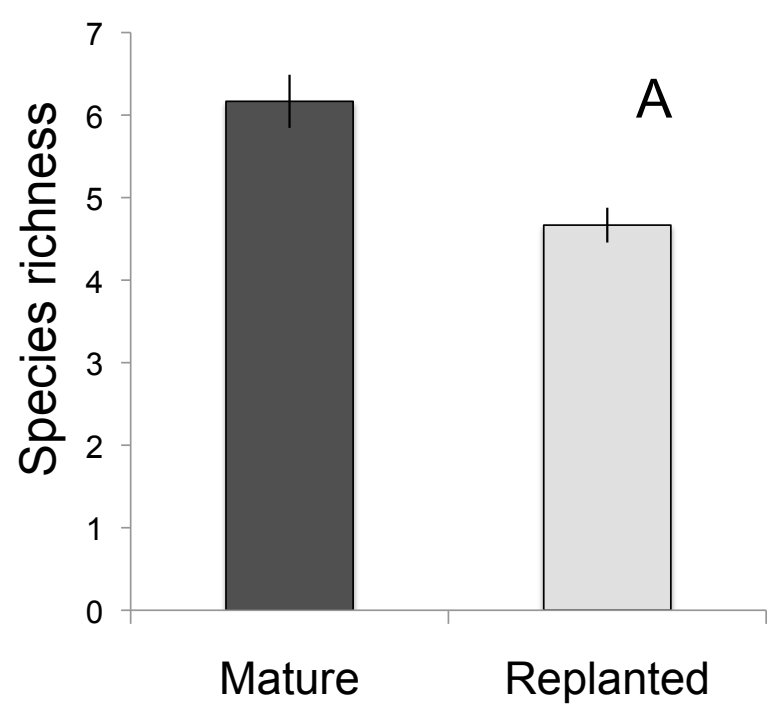

615

616

617

618

619

620

621

622

623

624

625

626

627

628
Oil Palm Replanting Reduces Frog Diversity

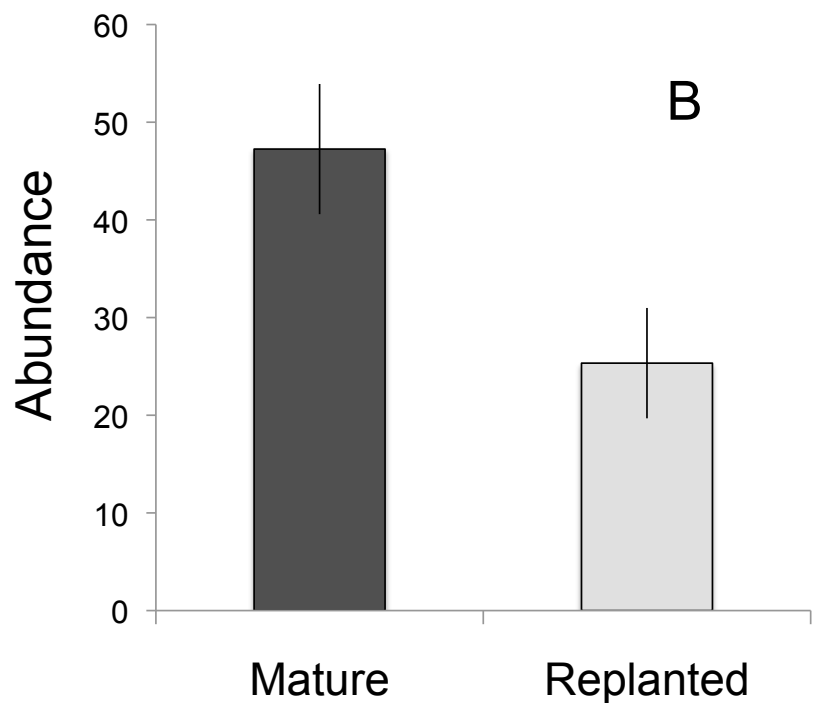




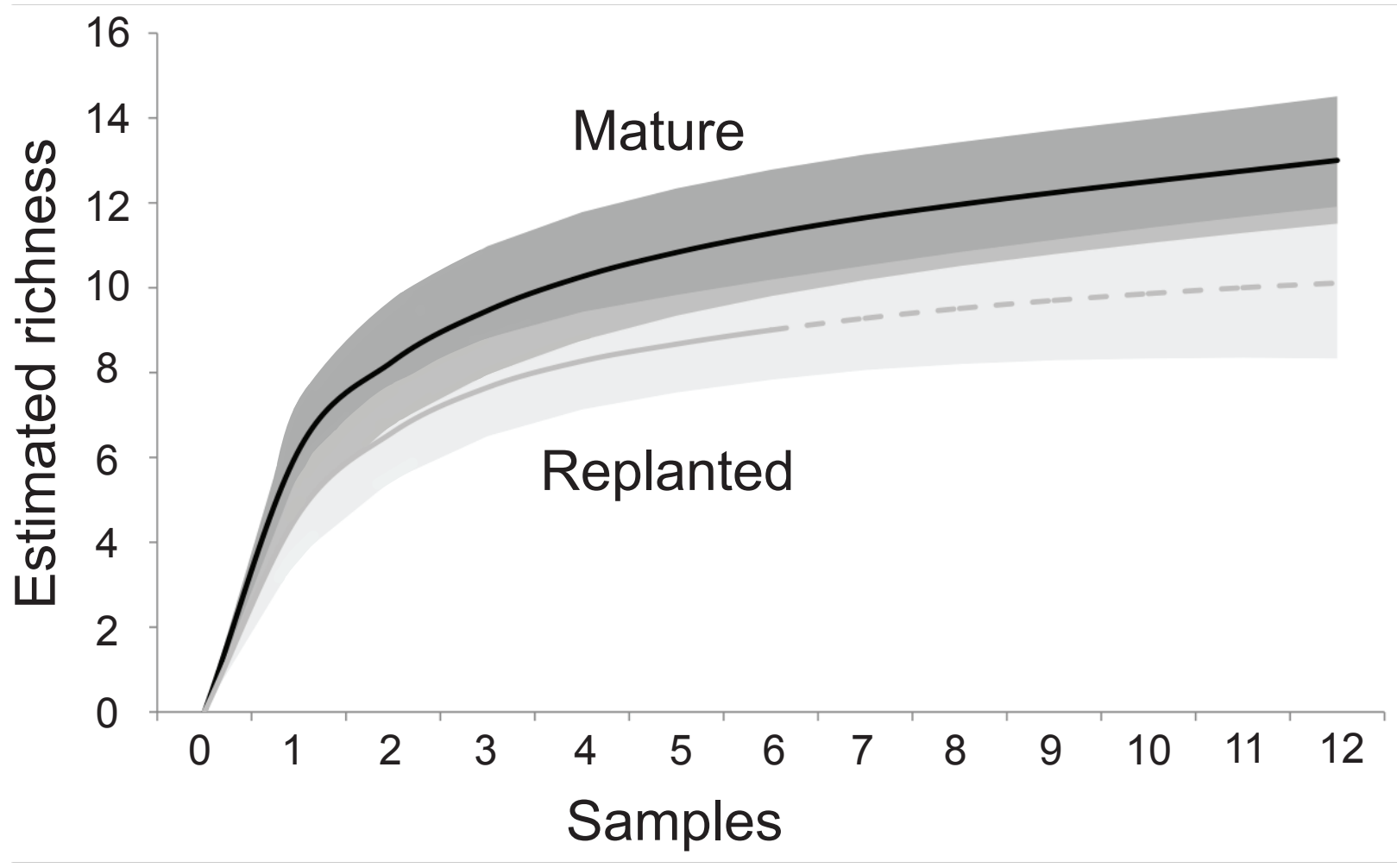




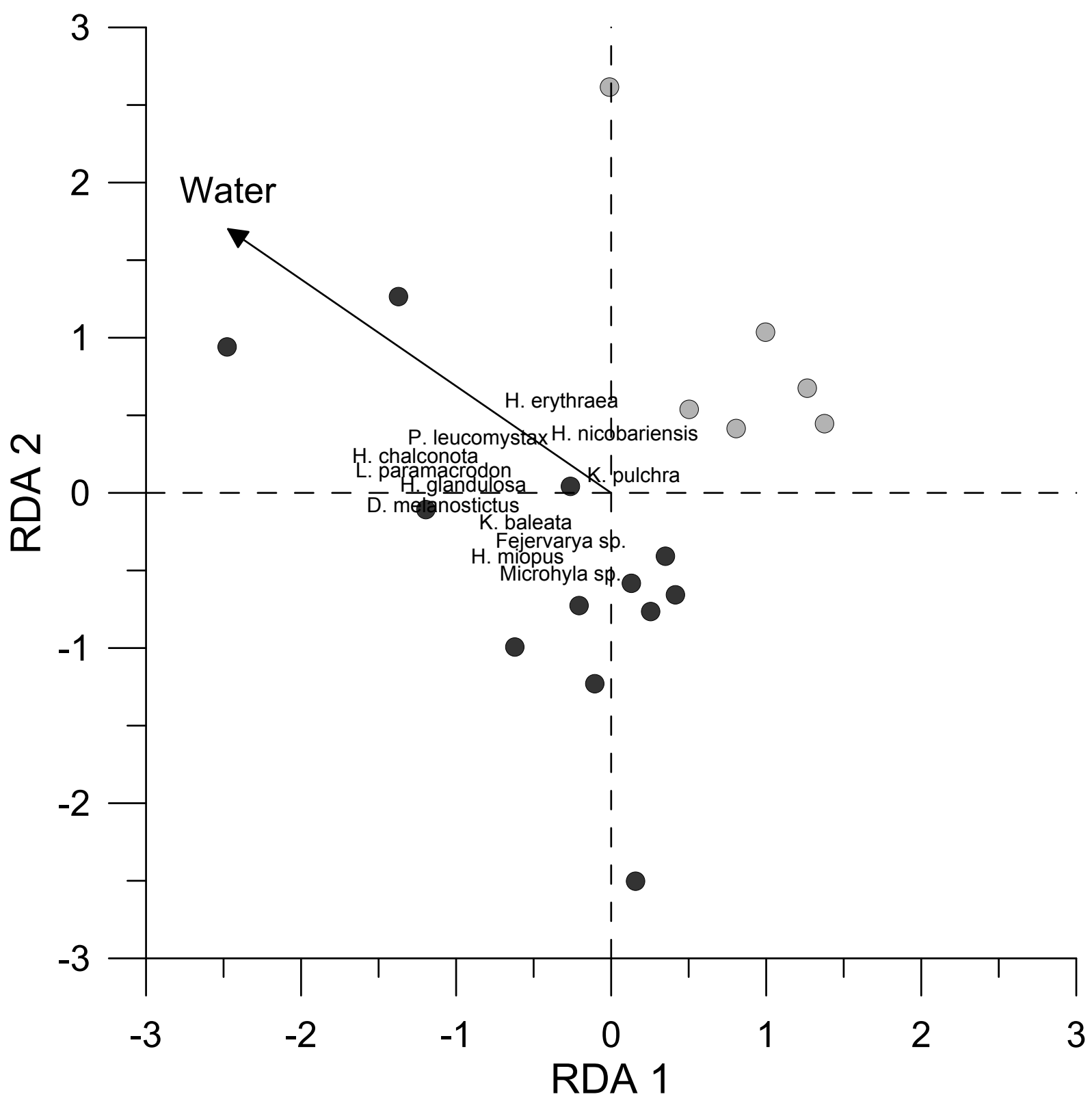

